\title{
The arthritis of Constantine IX
}

\author{
D. E. CAUGHEY \\ Department of Rheumatology, Auckland Hospital Board and Department of Medicine, \\ University of Auckland School of Medicine, Auckland, New Zealand
}

Early clinical descriptions of rheumatoid arthritis are rare, and it has been suggested (Boyle and Buchanan, 1971) that for this reason the paucity of evidence of the disease in early skeletons (Copeman, 1969; Grossman, 1966; Ruffer, 1918; Smith and Jones, 1910), the lack of reference to the disease in the Bible or in the works of Shakespeare (Ehrlich, 1967), and the failure to depict the deformities of the disease by the classical masters of the Dutch, French, Italian, and Spanish schools of painting, that this is a disease of comparatively recent times.

The arthritis of the Emperor Constantine IX (c. 980-1055), in keeping with theories at the time, was thought to be due to a disturbance of the basic humours. The account of the Emperor's illness was written by Michael Psellus in the Chronographia (Psellus, 1063), which forms an important source of the history of the Eastern Roman Empire from A.D. 976 to 1078.

Michael Psellus was a Christian scholar, an adviser, friend, and tutor to successive Emperors, and he used his first-hand information of politics and the imperial court to write a memoir of his own times. His account vividly portrays the Byzantine way of life. He studied medical treatises, and is said to have practised the art of medicine. He was a careful observer of people and character studies are recorded with considerable psychological insight.

Constantine Monomachus, who came to the throne because he was the third husband of the Empress Zoë, ruled between A.D. 1042 and 1055 (Figure, overleaf). Psellus described him as having an attractive personality, remarkable beauty, and considerable athletic prowess, and stated that he was an effective ruler and a good Christian, under whose rule the Empire prospered. After two paragraphs about the Emperor's appearance, Psellus devoted considerable space to the description of the Emperor's illness, which is here quoted in full.

'Such was the beauty with which the Emperor was endowed when he ascended the throne, but a year had not gone by before Nature, in her efforts to glorify him, seemed to falter before such wonder and delight; it was as if they gave up the task in exhaustion, and then des- troyed his strength and ruined his manhood. At all events there can be no doubt that a radical change took place in the disposition of the primary substances in his body (that is, the basic humours), and they accumulated, in proportions that made harmony impossible, in his feet and the cavities of his joints, then in his hands. Later they descended in great waves on the muscles themselves, and the bones in his back, shaking him through and through, like seacurrents converging on a ship of burthen which had started its voyage in calm water.

'The symptoms of his disease were not all immediately apparent. The humours first flowed into his feet, and at once he was compelled to take to his bed. If he had to walk at all, he did so with the help of other people. Thes illness was recurrent, and it was evident that the flux continued for a certain number of days, followed by an equal period of rest. Later on, the intervals between these attacks diminished and his relief became short-lived. As this condition developed, the flux gradually approached his hands, then with a kind of upward flow, the humours attacked his shoulders, and finally occupied the whole of his body. The result was that every one of his members, swamped by the terrible flux, lost the ability to perform its natural functions. His muscles and ligaments were out of place, his limbs ceased to work in harmony, with consequent lack of general equilibrium and a development of nervous exhaustion. I myself saw his fingers, once so beautifully formed, completely altered from their natural shape, warped and twisted with hollows here and projections there, so that they were incapable of grasping anything at all. His feet were bent and his knees, crooked like the point of a man's elbow, were swollen, making it impossible for him to walk steadily or to stand upright for any length of time. Mostly he lay on his bed, and, whenever he wished to give audience, others had to prop him up and make him comfortable.

'For the sake of the city populace he considered it his unavoidable duty to attend the imperial processions, and it was on these occasions that he complained most bitterly. However, through the skill of his equerry, he was arranged and settled in the saddle, and since he found breathing difficult once he was mounted, and as the bridle hung useless, attendants, tall, strong men, used to hold him up on either side as he rode. So, keeping him steady on right and left, like some heavy load, they would convey him to his intended destination. Yet, even in these distressing conditions, he never entirely forgot his normal habits. He would assume an expression of great benevolence, and 
FIG URE Part of a mosaic depicting Christ with Constantine Monomachus on his right. The complete mural has the Empress Zoë on the left. Constantine was the Empress' third husband and possibly only the head and lettering were changed with successive marriages. Reproduced with the publishers' permission from 'Constantinople. Byzantium-Istanbul', by Prof. D. T. Rice, with photographs by W. Swaan, published in 1965 by Elek Books, London.

This mosaic is to be found in the South Gallery of Agia Sophia, the cathedral founded by the Emperor Justinian in Constantinople in A.D. 537

even moved and changed his position (the only time he ever did so unaided) so that the spectators were not really sure that he was in pain, or that his body was suffering from paralysis. Such were the arrangements made for him at the processions. Even the stones of the pavement were covered with carpets, to prevent his horse slipping on a smooth surface. Of course it was different in his palace, for there he was carried on a litter, and he used to pass from one apartment to another and be conveyed wherever he wished. But if the flux came on-what awful agonies he endured!

'Even while I write this history I am still absolutely amazed to think how the man was able to bear the excruciating pain of those attacks during that period of his life. Paralysis followed paralysis in rapid succession, impairing the parts still untouched by the disease and dislocating what was still coherent. He did not know how to lie on his bed so as to enjoy a proper rest: every position was uncomfortable. His valets would hold up and support his poor body on either side until after much experiment they discovered the posture which afforded some relief to him. Then they would arrange him and make him comfortable, with cushions so placed that he might be kept firm in position. But change of posture was not the only thing that caused him pain: even his tongue hurt him when he was speaking, and the slightest movement of the eyes set the humours in motion. Thus he remained absolutely still, never turning in either direction.

'While on the subject of this illness, I solemnly declare, and I call to God to witness the truth of my words, that Constantine, despite the dreadful troubles that exhausted and overwhelmed him, despite the altogether pitiable condition in which he found himself, never once allowed a word of blasphemy against God to escape his lips. In fact, if he saw anyone else dismayed at his sufferings, he sent him from his presence with more than usual severity. The misfortune, he said, was laid upon him as a punishment. More often he referred to it as a "curb on his nature". Indeed, he was afraid of his instincts, and he used to say, "when they refuse to give way to reason, they yield to bodily pain. My body is afflicted, but at least the unruly desires of my heart are now repressed". So he 
argued about his sufferings like a philosopher, and if one set aside all else that he did, and considered him in this matter only, surely one would say that here was a godly man.'

Constantine Monomachus died in A.D. 1055 'of a chill', after having had his arthritis for 12 or 13 years. Psellus says that the Emperor rallied just before his death, but only to curse his fate.

Psellus describes well, in a language that many doctors have all but forgotten how to use, a progressive inflammatory polyarthritis with involvement of soft tissues and increasing deformities. We are not told of skin lesions or nodules, although the latter may have caused some of the projections described. Although in a later passage Psellus comments that the Emperor 'was naturally inclined to sexual indulgence but could find no satisfaction in cheap harlotry', it seems unlikely that the type of arthritis that the Emperor developed was Reiter's disease as we know it. This case history would seem to describe best a man with rheumatoid arthritis. If we accept the dates given in the Encyclopaedia Britannica c. 980-1055, the onset of his arthritis occurred about the age of 63 .

The evidence of rheumatoid arthritis in early skeletons is poor and fusion of the carpus of an elbow, as described by Smith and Jones (1910), is more likely to be due to infection than to rheumatoid arthritis. The lack of evidence in skeletons does not of course rule out its occurrence, for cartilage changes are poorly seen in this material. May (1897) has given a convincing description in a mummy found in a cemetery of the 5th Dynasty at Deshasheh in Egypt. One would have expected more evidence in skeletons, if the prevalence in the population was at the level of 1 or 2 per cent. which is now thought to prevail (Lawrence, Behrend, Bennett, Bremner, Burch, Gofton, O'Brien, and Robinson, 1966) in most parts of the world.

The failure to describe rheumatoid arthritis in the Bible and in Shakespeare (Ehrlich, 1967) has been noted. A possible description by Aretaeus in A.D. 100 has been quoted by Hormell (1940), but a translation of the original was not available to me (Aretaeus, trans. Adams, 1856).

The absence of pictures showing sufferers with rheumatoid arthritis in the classical schools of Italian, Dutch, and Spanish painting is surprising in times when deformity was often depicted.

Clinicians of the calibre of Heberden seem not to have described rheumatoid arthritis, and credit for the first differentiation of the disease is usually given to Landré-Beauvais (1800), over 700 years after the death of Constantine Monomachus (Parish, 1963).

Although Sydenham is usually stated not to have described rheumatoid arthritis, Karsh and McCarthy (1960) give him credit for the first clinical description of the disease and Welfling (1966) has drawn attention to a paragraph from Sydenham (1685) in which is described in a few lines what might well appear to be polyarticular rheumatoid arthritis.

'Indeed it may happen that where the said pains will have harassed over many days and very often, they may at length desist spontaneously; and meanwhile the sufferer may be deprived of all movement of his members until death, with the joints of the fingers as though reversed, and with swellings as in arthritis, knotted and protruding on the inside rather than on the dorsal part of the fingers; nevertheless he may have a good stomach, and tolerate other aspects of life well.'

Psellus' account of the Emperor's illness is drawn to the attention of rheumatologists because of its general interest and possible epidemiological implications, its intrinsic merit as a piece of good descriptive medical writing, and also, in part, as a reply to Professor Watson Buchanan's challenge to find good evidence of rheumatoid arthritis before the 16th century. Sydenham's reference to the recurring torture might also be reconsidered as an early description of clinical rheumatoid arthritis.

Prof. E. R. A. Sewter gave permission and encouragement to quote from his translation of Psellus' work. Mr. H. D. Erlam, Librarian to the University of Auckland Medical School, translated the passage from Sydenham. Dr. J. L. Newman first directed my attention to the Emperor's arthritis. The help of these men and of my secretary is gratefully acknowledged.

\section{References}

Aretaeus 'The Extant Works of Aretaeus the Cappadocian', trans. Francis Adams, 1856, pp. 362-365. Sydenham Society, London

Boyle, J. A., AND Buchanan, W. W. (1971) 'Clinical Rheumatology', p. 74. Blackwell Scientific Publications, Oxford and Edinburgh

COPEMAN, W. S. C. (1969) 'Textbook of the Rheumatic Diseases', 4th ed. pp. 6-7. Livingstone, Edinburgh and London

EhrLich, G. E. (1967) Ann. rheum. Dis., 26, 562 (Shakespeare's rheumatology)

Grossman, B. J. (1966) Proc. Inst. Med. Chicago, 26, 114 (Rheumatoid arthritis from prehistory to Hippocrates)

HoRMel, R. S. (1940) New Engl. J. Med., 223, 754 (Notes on the history of rheumatism and gout)

KaRSH, R. S., AND MCCARTHY, J. D. (1960) Arch. intern. Med., 105, 640 (Archaeology and arthritis)

Lawrence, J. S., Behrend, T., Bennett, P. H., Bremner, J. M., Burch, T. A., Gofton, J., O’Brien, W. M., AND RoBinson, H. (1966) Ann. rheum. Dis., 25, 425 (Geographical studies in rheumatoid arthritis)

LANDrÉ-Beauvais, A. J. (1800) Thèse, Paris (Doit-on une nouvelle espèce de goutte sous la denomination de goutte asthénique primitive?) 
MAY, W. P. (1897) Brit. med.J., 2, 1631 (Rheumatoid arthritis (osteitis deformans) affecting bones 5,500 years old) Psellus, M. (c. 1063) 'Fourteen Byzantine Rulers: The Chronographia of Michael Psellus', trans. from Greek by E. R. A. Sewter, 1966, p. 397. Penguin Classics, Harmondsworth

PARISH, L. C. (1963) Arthr. and Rheum., 6, 138 (An historical approach to the nomenclature of rheumatoid arthritis) Ruffer, A. (1918) J. Path. Bact., 22, 212 (Arthritis deformans and spondylitis in Ancient Egypt)

Smith, G. E., AND Jones, F. W. (1910) 'The Archaeological Survey of Nubia: Survey Department Report for 1907-1908', vol. 2, 'Report on The Human Remains', p. 270. Cairo National Print Department, Egypt

Sydenham, T. D. (1685) 'Observationes Medicae circa Morborum Acutorum Historiam et Curationem. VI

Rheumatismus', Caput V, Section 2, 4th ed. Printed by W. Kettilby, London. As contained in the Opera Omnia, ed. W. A. Greenhill, 1844. Sydenham Society, London

Welfling, J. (1966) Presse méd., 74, 1502 (Trois grands médecins anglais) 